\title{
【論文】
}

\section{焼却残椬中の $\mathrm{Pb}$ の化合物形態解析}

\author{
山本 浩* ・名越正泰** 横 山隆*** \\ 高岡昌輝 $* * * *$ ・武田信生 $* * * *$
}

【要 旨】ストーカ式ごみ焼却炉から排出される焼却残渣に含有される微量元素 $\mathrm{Pb}$ の化合物形態を, $\mathrm{X}$ 線吸収微細構造法（XAFS）を用いて解析した。焼却炉底灰に含まれる $\mathrm{Pb}$ の化合物形態は, $\mathrm{Pb}^{2+}$ の酸化物形態であり, 非晶質の $\mathrm{PbSiO}_{3}$ を形成していると推測された。ボイラ灰は $\mathrm{Pb}^{2+}$ の塩化物ある いは炭酸化物之, 焼却炉底灰同様に非晶質の $\mathrm{PbSiO}_{3}$ との混合物と推測された。減温塔灰は非晶質の $\mathrm{PbSiO}_{3}$ のみを含み, 塩化物等の存在は確認されなかった。集塵灰では, 同じ工場でむ排出される時期 が異なると, $\mathrm{Pb}$ が塩化物形態の場合と, 非晶質の $\mathrm{PbSiO}_{3}$ 単独で存在することが示唆できた。

キーワード：焼却残渣， $\mathrm{Pb}$ ，化合物形態，XAFS，複合酸化物

\section{1.はじめに}

資源循環型社会の構築に向けて, 廃棄物処理過程から 排出される焼却炉底灰, ボイラ死, 減温塔灰, 集塵死等 の焼却残椬の無害化や資源化・有価金属回収システムの 確立が期待されている。そのシステム構築には, 焼却残 椬の安全性確保や高効率の成分分離技術が必要である。 そのためには焼却残椬に含まれる有害元素の化合物形態 を把握し，その結果を成分分離に有利な化合物形態へ制 御することを狙った焼却処理や無害化処理の条件適正化 に反映させていく必要がある。特に, 焼却炉底灰, 集塵 灰に含まれる重金属類として比較的含有量が高い $\mathrm{Pb}$ の 無害化・資源化は重要であると考えられる。

焼却灰, 飛灰中の $\mathrm{Pb}$ の無害化技術においては, 多く の新技術検討がなされている。ここで, 重金属類の溶出 量は化合物形態により大きく異なるため, $\mathrm{Pb}$ の化合物 形態を明らかにすることで, 無害化処理した焼却扊, 飛 灰中の $\mathrm{Pb}$ が安定した化合物形態になっていることの検

原稿受付 2006.4. 3 原稿受理 2006.11.13

* JFE 技研(株)

** JFE スチール(株)

*** JFE エンジニアリング(侏)

**** 京都大学大学院工学研究科 連絡先：干 211-0855 川崎市川崎区南渡田町 $1-1$

JFE 技研(株) 山本 浩 E-mail : h-yamamoto@jfe-rd.co.jp
証が必要と考えられる。また, 焼却炉底灰, ボイラ灰, 減温塔灰, 集塵灰中の $\mathrm{Pb}$ の化合物形態が明らかになる と, 雾囲気温度やガス組成データと併せた検討にて現状 の焼却プロセスにおける $\mathrm{Pb}$ 挙動がより明確になってく る。すると, $\mathrm{Pb}$ の化合物形態制御に有利な焼却プロセ ス確立への取り組みにおいてその開発方向性をより明確 にできる。併せて, 焼却灰のエージング処理や焼成処理 等, 新規の無害化技術の開発において, $\mathrm{Pb}$ の不溶化機 構解明・検証と最適条件の導出における有益な基盤デー 夕が得られる可能性があると考えられる。しかし, 焼却 残椬中，あるいはそれを無害化処理した際の $\mathrm{Pb}$ 化合物 形態を解析した報告は少ない(1-3)。

焼却残椬に含まれる有害元素の化合物形態を解析する ための方法として,「破壊分析」と「非破壊分析」があ げられる。「破壊分析」とは, 溶媒に試料を溶解・抽出 させる簡便な操作にて, その溶解性・抽出率から化合物 形態を推測する方法である。「破壊分析」の課題は, サ ンプルが少量の場合は分析が難しく, 溶解・抽出の過程 で化合物形態が変化する場合が推測される。「非破壊分 析」では, XRDのように少量のサンプルを破壊するこ となく解析を進めることができ, 先述の課題を解決でき る。「非破壊分析」を用いて焼却残椬に含まれる有害元 素の化合物形態を解析した報告は, 大別して以下のもの がある。

1) X 線回折法 (XRD) を用いた化合物形態解析 ${ }^{1)}$

2) XPS を用いた化合物形態解析 ${ }^{2,3)}$ 
この中で，1）X 線回折法（XRD）は, 含有量が数 $\mathrm{wt} \%$ 未満である微量元素の化合物形態の直接的な解析 は困難であるがゆえ，水洗などで可溶性成分を除去，濃 縮させた後の XRD による形態解析が試みられている。 しかし, その化学操作の過程で目的物質の化合物形態が 変化している可能性がある。また，2）XPS を用いた 化合物形態解析は，その測定原理から試料表面のみの情 報しか得られず，バルクでの情報は得られない。このよ うに，焼却残椬中に含まれる微量の有害金属の化合物形 態特定が望まれているにあかかわらず，直接的に微量成 分の化合物形態特定が非常に難しいことが，微量元素で ある有価金属の化合物形態を制御し，資源化・有価金属 回収に対応可能である焼却プロセス確立の障害となって いた。

近年, これらの問題を解決し, 微量元素の化合物形態 解析が可能な方法として, 放射光用電子蓄積リングから 得られる高輝度 $\mathrm{X}$ 線を用いた $\mathrm{X}$ 線吸収微細構造法 ( $\mathrm{X}^{-}$ ray Absorption Fine Structure; XAFS) が用いら れつつある ${ }^{4,5)}$

筆者らは，この放射光 XAFS 解析法を用いて液体キ レート剂による焼却飛灰含有鉛の不溶化機構を明確化し, 本手法が焼却残椬含有の微量元素における化合物形態解 析に有効であることを確認した6)。また，焼却・溶融飛 灰に含まれる様々な微量元素の化合物形態の XAFS 解 析結果が得られはじめ, 焼却残椬の資源化・有価金属回 収に向けて貴重な知見が得られてきている7-12)。しかし ながら，廃棄物分野におけるこの手法の化合物形態解析 に関する報告はまだまだ少なく，知見の蓄積が必要であ る。

本報では，ごみ焼却施設から排出される焼却残椬中の 有害元素において,

・複数のごみ焼却施設から採取した焼却残椬に含まれ る $\mathrm{Pb}$ において，XAFS の中でも化学結合状態に高 感度な XANES (X-ray Absorption Near Edge Structure）スペクトルを獲得し，標準物質スペク トルとの比較から化合物形態を解析する

- 焼却炉底灰, ボイラ死, 減温塔灰, 集塵灰含有の $\mathrm{Pb}$ の化合物形態を解析する

ことで，焼却残椬に含まれる有害金属のうち，最も無害 化処理の必要性が高い $\mathrm{Pb}$ の化合物形態を明らかにする ことを目的とした。

\section{2. 実 験 方 法}

\section{1 試 料}

全連続ストーカ式ごみ焼却炉から採取した 5 種の焼却
炉底灰 $\mathrm{A} \sim \mathrm{E}$ を供試試料とした。焼却炉底灰 $\mathrm{A}, \mathrm{B}$ は, 焼却温度 $800 \sim 1,200^{\circ} \mathrm{C}$ の焼却炉から排出された後の焼 却炉底灰搬送コンベアから乾燥状態， $\mathrm{C} \sim \mathrm{E}$ は灰押出機 出口から湿潤状態にて採取した。また，焼却炉底灰 $\mathrm{A}$ を採取した焼却工場では，同時にボイラ死と集塵死を， 焼却炉底灰 $\mathrm{E}$ の採取工場ではボイラ灰，減温塔灰，集 塵灰も採取した。ボイラ灰は， $850 \sim 950^{\circ} \mathrm{C}$ から $250^{\circ} \mathrm{C}$ にまで排ガスを冷却する廃熱ボイラ内を通過する際に, 廃熱ボイラ下部へ落下した灰を排出するダブルフラップ ダンパにて採取した。減温塔灰 $\mathrm{E}$ は, 入口温度 $250^{\circ} \mathrm{C}$ から $160^{\circ} \mathrm{C}$ まで冷却する減温塔内を通過する際に, 減温 塔下に落下した死を排出するダブルフラップダンパから 採取した。集塵灰は排ガス温度 $160^{\circ} \mathrm{C}$ のバグフィル夕か ら排出された後のコンベア上で採取した。これらの焼却 施設 $\mathrm{A} \sim \mathrm{E}$ では乾式法（消石灰吹き込み）による有害ガ ス除去設備が設置されている。測定に供した試料の成分 含有量分析結果を分析方法とともに Table 1 に示す。

\section{2 実験（分析・解析）方法}

\subsubsection{XAFS 測定法の原理}

本研究では, 焼却残椬中の微量 $\mathrm{Pb}$ の化合物形態解析 に，放射光 XAFS 法を用いた。以下に，放射光 XAFS 解析について簡単に説明する。

直径数十〜数百 $\mathrm{m}$ の電子蓄積リング中において光速 に近い速度で運動している電子より，接線方向に放射さ れる放射光から得られる連続 X 線が放射光 (Synchrotron Radiation; SR) である。分光器（モノクロメー ター）を用いて放射光を単色化し，波長を吸収端の前後 で走査して試料に X 線を照射する。このとき，X線の 一部は試料に吸収されるが，この際の試料の X 線吸収 に対応する信号を測定するとX 線吸収スペクトルが得 られる。X 線吸収スペクトルには原子の内殼電子の束 縛エネルギーに対応する波長に, 吸収率が急激に増加す る吸収端が現れる ${ }^{4,5)}$ 。Fig. 1 に放射光 XAFS 法におけ る基本的な機器構成例，Fig. 2 に $\mathrm{PbO}$ にて得られる $\mathrm{Pb}$ L 3 XAFS スペクトル例を示す。

放射光 XAFS 法を用いることで，Fig. 2 中の X 線 吸収スペクトルにおける吸収端近傍の微細構造（X 線 吸収端微細構造：XANES), および吸収端より高エ ネルギー側の振動構造（拡張 X 線吸収端微細構造：

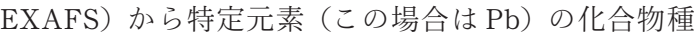
を判定すること，元素周囲の局所的な原子配置を評価す ること等ができる。試料は大気中でも測定を実施でき, 固体のみならず液体であ測定可能であり，スラグなどの 非晶質試料む解析可能である。 
Table 1 Chemical composition of municipal solid-waste incinerator residues

\begin{tabular}{|c|c|c|c|c|c|c|c|c|c|c|c|c|c|}
\hline \multirow{2}{*}{ Elements } & \multirow[t]{2}{*}{ Unit } & \multicolumn{2}{|c|}{$\begin{array}{l}\text { Grate ash } \\
\quad \text { (dry) }\end{array}$} & \multicolumn{3}{|c|}{$\begin{array}{l}\text { Grate ash } \\
\text { (wet) }\end{array}$} & \multicolumn{2}{|c|}{ Boiler ash } & \multirow{2}{*}{\begin{tabular}{|c|}
$\begin{array}{c}\text { Cooling } \\
\text { tower ash }\end{array}$ \\
$\mathrm{E}$ \\
\end{tabular}} & \multicolumn{3}{|c|}{ APC residue } & \multirow{2}{*}{$\begin{array}{l}\text { Analysis } \\
\text { methods }\end{array}$} \\
\hline & & $\mathrm{A}$ & B & $\mathrm{C}$ & $\mathrm{D}$ & $\mathrm{E}$ & $\mathrm{A}$ & $\mathrm{E}$ & & A & $E-1$ & $E-2$ & \\
\hline $\mathrm{Ca}$ & \multirow{8}{*}{ wt $\%$} & 13 & 17 & 18 & 12 & 19 & 12 & 24 & 23 & 25 & 17 & 20 & AA \\
\hline $\mathrm{Si}$ & & 18 & 13 & 10 & 21 & 13 & 7.4 & 6.4 & 8.5 & 4.2 & 7.8 & 6.6 & ICP-MS \\
\hline $\mathrm{Al}$ & & 7.1 & 8.1 & 8.5 & 7.7 & 6.6 & 4.9 & 5.5 & 7.3 & 2.6 & 5.1 & 4.1 & ICP-MS \\
\hline $\mathrm{Fe}$ & & 5.2 & 2.6 & 2 & 4.2 & 5.3 & 2.8 & 1.2 & 1.5 & 0.64 & 0.79 & 0.65 & ICP-MS \\
\hline $\mathrm{Na}$ & & 2.7 & 2.1 & 1.6 & 2.0 & 4.1 & 5.9 & 3.5 & 3.4 & 4.0 & 5.5 & 4.0 & AA \\
\hline $\mathrm{K}$ & & 1.3 & 1.1 & 0.8 & 2.3 & 1.5 & 5.4 & 2.0 & 1.7 & 4.3 & 4.6 & 6.1 & AA \\
\hline $\mathrm{Cl}$ & & 0.6 & 0.30 & 0.9 & 0.1 & 0.61 & 3.3 & 1.2 & 2.7 & 27 & 21 & 18 & IC \\
\hline $\mathrm{T}-\mathrm{S}$ & & 0.07 & 0.23 & 0.22 & 0.05 & 0.13 & 8.5 & 2.4 & 1.7 & 1.7 & 4.9 & 3.4 & IC \\
\hline $\mathrm{Cu}$ & \multirow{8}{*}{$\mathrm{mg} / \mathrm{kg}$} & 2900 & 2100 & 3100 & 1700 & 2100 & 960 & 350 & 400 & 1200 & 970 & 770 & ICP-MS \\
\hline $\mathrm{Zn}$ & & 2900 & 1300 & 4200 & 1400 & 1800 & 16000 & 6300 & 6100 & 9300 & 22000 & 13000 & ICP-MS \\
\hline $\mathrm{Pb}$ & & 640 & 210 & 2400 & 210 & 710 & 3000 & 840 & 500 & 2300 & 5600 & 3900 & ICP-MS \\
\hline $\mathrm{Cd}$ & & $<5$ & $<5$ & $<5$ & $<5$ & $<5$ & 61 & 17 & 14 & 100 & 180 & 140 & ICP-MS \\
\hline $\mathrm{T}-\mathrm{Hg}$ & & $<0.05$ & $<0.05$ & $<0.05$ & $<0.05$ & $<0.05$ & $<0.05$ & $<0.05$ & 0.28 & 4.7 & 45 & 11 & AA \\
\hline $\mathrm{Cr}$ & & 250 & 310 & 430 & 200 & 400 & 280 & 310 & 370 & 50 & 430 & 400 & ICP-MS \\
\hline As & & $<5$ & $<5$ & $<5$ & $<5$ & $<5$ & $<5$ & 6 & $<5$ & $<5$ & 20 & 76 & AA \\
\hline $\mathrm{Se}$ & & $<5$ & $<5$ & $<5$ & $<5$ & $<5$ & $<5$ & $<5$ & $<5$ & $<5$ & $<5$ & 6 & AA \\
\hline
\end{tabular}

AA : atomic absorption spectrometer ICP-MS : inductively coupled plasma mass spectrometry IC : ion chromatography

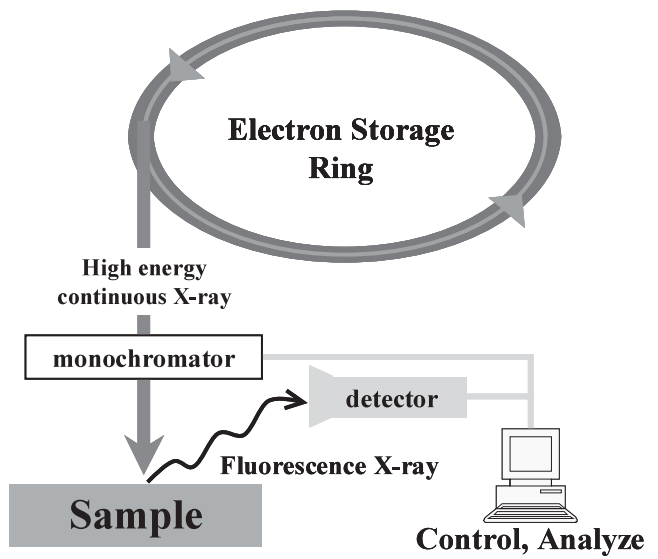

Fig. 1 Experimental apparatus for X-ray Absorption Fine Structure

\subsubsection{XAFS 測定方法}

XAFS 測定は, 兵庫県播磨科学公園都市にある(財高 輝度光科学研究センターの高輝度放射光施設 SPring -8 のビームライン BL 01 B 1 にて 2 回にわたって実施した。 大気雾囲気で測定を行い, 焼却残椬試料は蛍光法, 標準 試料は透過法で行った。測定器は, 19 素子半導体検出 器あるいはライトル検出器を用いた。試料はめのう乳鉢

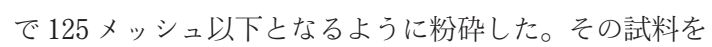
IR 用試料錠剤成型器を用いてペレット化・シールし, 測定器の試料フォルダにメンディングテープで固定した。 測定時期の違いによるスペクトルのエネルギー補正は,

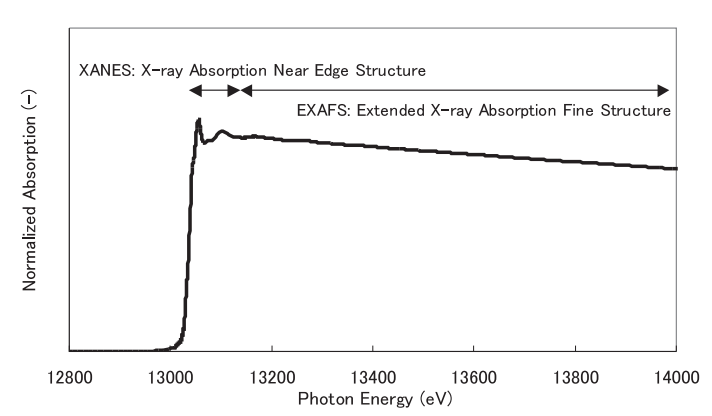

Fig. $2 \mathrm{~Pb} \mathrm{~L} 3$ XAFS spectrum of $\mathrm{PbO}$

標準試料 $\mathrm{PbO}$ のピークトップにて補正した。

\section{2 .3 試薬標準試料と試薬から合成した標準試料}

標準試料には, 関東化学特級の $\mathrm{PbCl}_{2}, \mathrm{PbS}, \mathrm{PbSO}_{4}$, $\mathrm{PbCO}_{3}, \mathrm{PbO}, \mathrm{PbO}_{2}$ を用いた。標準試料は, スペクトル の $\mathrm{S} / \mathrm{N}$ 比がもっとも良好になる量を窒化矹素 (BN) 粉 末と混合し, IR 用錠剂成型器にてペレット状に成形し, ポリエチレン袋に封入した。

この他にXAFS 解析に供した標準試料として, 焼却 炉中で生成すると想定された複合酸化物 $\mathrm{PbSiO}_{3}$ を関東 化学特級の $\mathrm{PbO}$ と $\mathrm{SiO}_{2}$ から合成して用いた。この化合 物を合成して標準試料とした根拠は 3.2 節にて詳細に述 べる。 $\mathrm{Pb}-\mathrm{Si}-\mathrm{O}$ 系化合物は結晶質と非晶質物質が知ら れており，それぞれ $\mathrm{Pb}$ に配位している第一近接原子の 配位数や原子間距離屯異なる ${ }^{13)}$ ため, 結晶質, 非晶質の $\mathrm{PbSiO}_{3}$ をそれぞれ次に示す方法で合成した。非晶質の 
$\mathrm{PbSiO}_{3}$ は $\mathrm{PbO}$ と $\mathrm{SiO}_{2}$ を等モル比にてめのう乳鉢にて 混合し, Pt るつぼ内で $1,200^{\circ} \mathrm{C}, 1 \mathrm{~h}$ 加熱保持直後に炉 内から取り出して急冷した。焼成温度 $1,200^{\circ} \mathrm{C}$ の設定理 由は，通常のごみ焼却炉の操業範囲にて発生する最高温 度から決定した。また, 結晶質の $\mathrm{PbSiO}_{3}$ は, $\mathrm{PbO}$ と $\mathrm{SiO}_{2}$ の等モル比混合物を $650^{\circ} \mathrm{C}, 6 \mathrm{~h}$ 加熱・炉冷後に粉 砕・混合した試料を再び $650^{\circ} \mathrm{C}, 6 \mathrm{~h}$ 加熱した。焼成温 度 $650^{\circ} \mathrm{C}$ の設定理由は, 融点より低い温度で加熱処理す ることで結晶化を進めるためである。以上の方法により， 結晶質と非晶質両方の複合酸化物 $\mathrm{PbSiO}_{3}$ を標準試料と して得た。

同様に， $\mathrm{Pb}-\mathrm{Al}-\mathrm{O}, \mathrm{Pb}-\mathrm{Fe}-\mathrm{O}$ 系の複合酸化物を合成 することを目的として，関東化学特級の $\mathrm{Al}_{2} \mathrm{O}_{3}, \quad \mathrm{Fe}_{2} \mathrm{O}_{3}$ にて $\mathrm{PbO}$ と等モル比で混合し， $650^{\circ} \mathrm{C}, 12 \mathrm{~h}$ 加熱・炉 冷，あるいは $1,200^{\circ} \mathrm{C}, 1 \mathrm{~h}$ 加熱保持直後に急冷して得 た試料を XRD（Philips X'pert MPD）にて解析した。

\subsubsection{XAFS スペクトル解析方法}

各種焼却残椬および標準試料の XAFS スペクトルは, 強度を規格化した後，スペクトルを比較することで各焼 却残椬中の化合物形態を推定した。放射光 XAFS 解析 にて得られるXANESスペクトル例として，Fig. 3 に

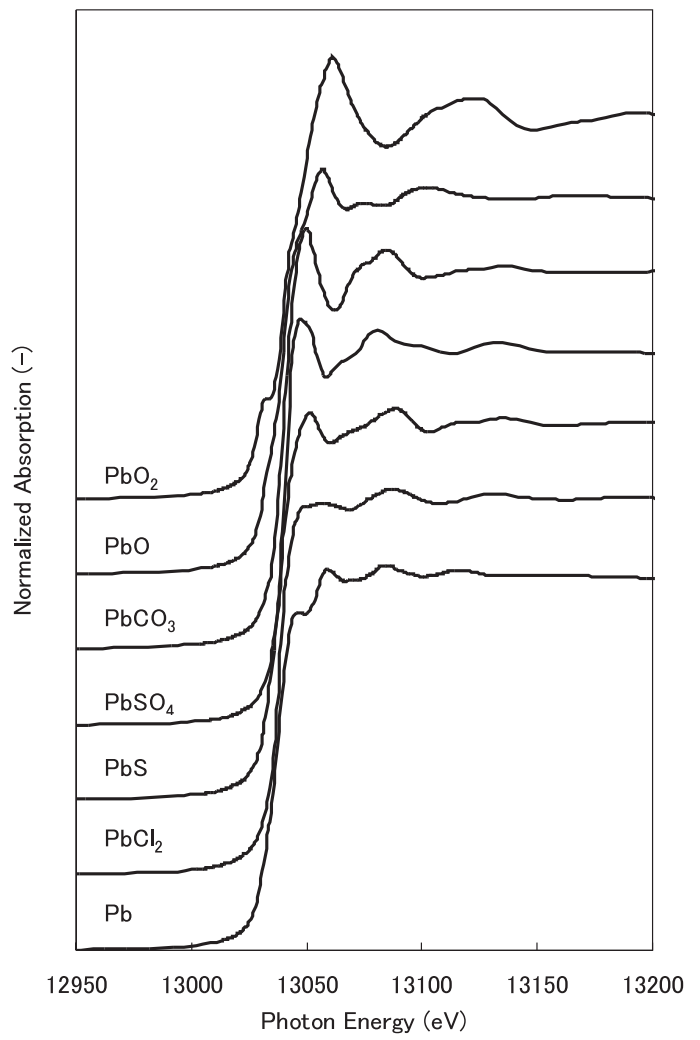

Fig. $3 \mathrm{~Pb} \mathrm{~L} 3$ edge XANES spectra for reference species of $\mathrm{Pb}$
試薬 $\mathrm{Pb}, \mathrm{PbCl}_{2}, \mathrm{PbS}, \mathrm{PbSO}_{4}, \mathrm{PbCO}_{3}, \mathrm{PbO}, \mathrm{PbO}_{2}$ の $\mathrm{Pb} \quad \mathrm{L} 3$ XANES スペクトルを示す。 $\mathrm{Pb}$ の価数の違い によって吸収端のピーク位置が異なることがわかる。ま た，同じ価数でも，各試料のスペクトル形状の違いから 指紋的に $\mathrm{Pb}$ 化合物種を判別することができる。した がって，未知試料の $\mathrm{Pb}$ スペクトル形状をこの標準スペ クトル形状と比較することで同定が可能である。他の元 素についても同様の手法で解析が可能である。

また，複数の未知の化合物形態が同時に存在してこの 方法で化合物形態を推定できない場合は，Linear Combination Fit (LCF) 法にて, 複数の標準物質の XAFS スペクトルを組み合わせてパターンフィッティングする ことにて同定する方法が報告 ${ }^{14)}$ されている。また，この LCF 法にて粒子状物質や焼却灰，飛灰中に含まれる化 合物形態種と含有率を推定した報告 ${ }^{15-18)}$ がある。本報告 では，解析ソフトウェア REX 2000 Ver. 2.3 .3 (株)リガ ク）を用いて焼却残椬スペクトルの LCF を行い，含ま れている化合物形態種と含有量を推測した。パターン フィッティングの方法としては，焼却残椬スペクトルと, 複数の標準試料スペクトルを合成したスペクトルとの差 違（残差； R 值）が最む小さくなるように収束計算を行 い，得られる各標準物質スペクトルの割合を，焼却残椬 試料に含まれている化合物形態の含有率として推測した。

\section{3. 結果および考察}

\section{1 焼却炉底灰に含まれる Pb の XANES スペクトル} 焼却炉底灰 $\mathrm{A} \sim \mathrm{E}$ の $\mathrm{Pb}$ L 3 XANES スペクトルと 5 種類の標準試料スペクトル形状を Fig. 4 に示す。 Fig. 4 中のスペクトルは，規格化した後，比較のため に各々のスペクトルを $\mathrm{y}$ 軸方向に順次シフトさせてあ る。

今回測定を行った焼却炉底灰の $\mathrm{Pb}$ 含有量範囲は 210 （焼却炉底灰 B，D）～2,400（焼却炉底灰 C） $\mathrm{mg} / \mathrm{kg}$ で あるが，Pb L 3 XANES スペクトルを得ることができ た。焼却炉底灰 $\mathrm{E}$ ではノイズがみられるが化合物形態 の判定を行うことは可能なスペクトルが得られた。

焼却炉底灰 $\mathrm{A} \sim \mathrm{E}$ の $\mathrm{Pb}$ スペクトルはすべて $\mathrm{Pb}$ が 2 価の $\mathrm{PbO}$ のスペクトル形状に類似し, $\mathrm{Pb}^{2+}$ の酸化物 が主として存在すると推察された。しかし，標準試料 $\mathrm{PbO}$ のスペクトル形状と比較して, 焼却炉底灰 $\mathrm{A} \sim \mathrm{E}$ のスペクトルは共通して，(1) $13,060 \mathrm{eV}$ 付近に存在する 第 1 ピークの強度が低下，(2) $13,070 \mathrm{eV}$ 付近に存在する 第 2 ピークが消失，等の特徵が見られた。焼却炉底灰 $\mathrm{A}$ と標準試料 $\mathrm{PbO}$ の XANES スペクトルの比較を Fig. 5 に示す。 


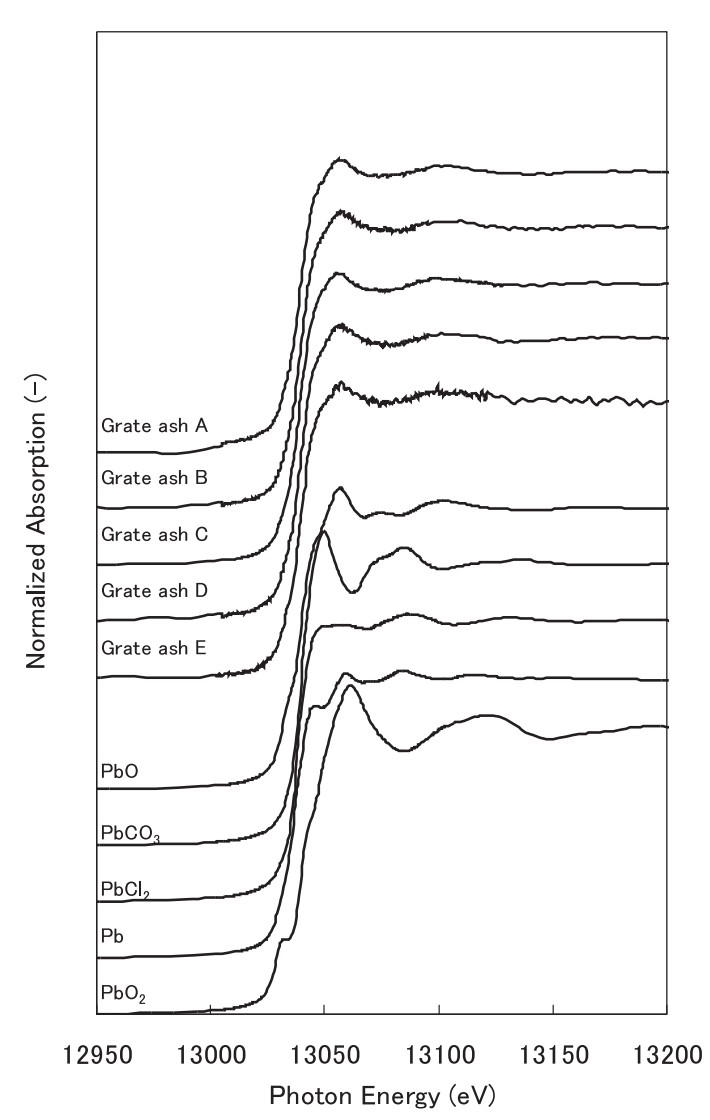

Fig. $4 \mathrm{~Pb} \mathrm{~L} 3$ edge XANES spectra for grate ash $\mathrm{A} \sim \mathrm{E}, \mathrm{PbO}, \mathrm{PbCO}_{3}, \mathrm{PbCl}_{2}, \mathrm{~Pb}$ and $\mathrm{PbO}_{2}$

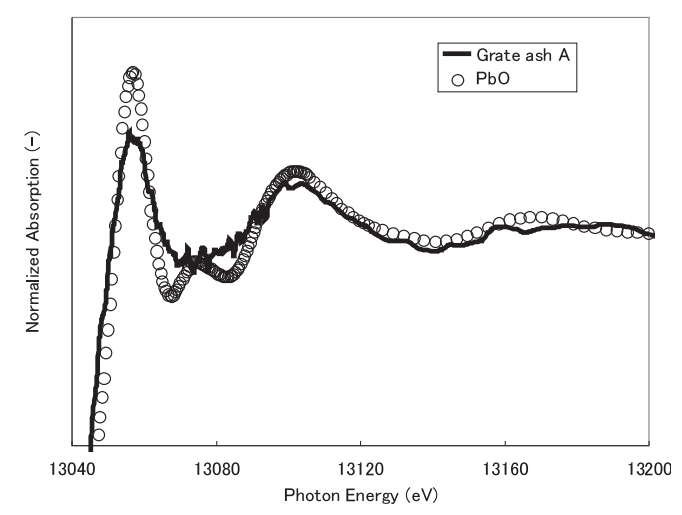

Fig. $5 \mathrm{~Pb} \mathrm{~L} 3$ edge XANES spectra for grate ash $\mathrm{A}$ and $\mathrm{PbO}$

このように，焼却炉底灰に含まれる $\mathrm{Pb}$ のスペクトル 形状が単純酸化物 $\mathrm{PbO}$ とは異なることから, 焼却炉底 灰に含まれる $\mathrm{Pb}$ 酸化物は単純酸化物ではない可能性を 得た。

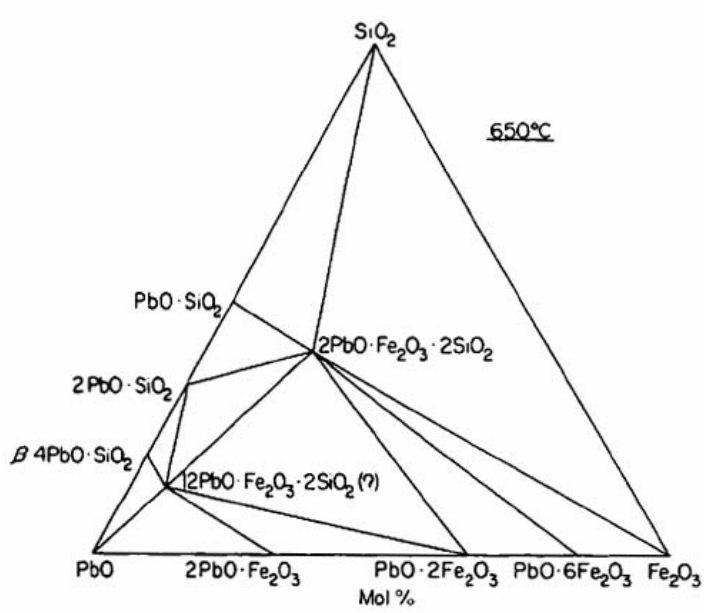

Fig. 6 The Phase-diagram for $\mathrm{PbO}-\mathrm{SiO}_{2}-\mathrm{Fe}_{2} \mathrm{O}_{3}$ system ${ }^{21)}$

\section{2 状態図と平衡計算による焼却炉内における $\mathrm{Pb}$ の 挙動推定}

前節3. 1 におけるXAFS 測定・解析では, 試薬標準 試料には単純化合物のみを用いた。しかし, 前節の結果 を受けて，ごみや灰には多種の元素が含まれていること から $\mathrm{Pb}$ が他の元素と高温の焼却炉内で複合酸化物を形 成している可能性を考えた。ここで, $\mathrm{Pb}$ が灰層内に存 在する他の元素との複合酸化物を形成するとした場合, どのような反応が進むかを検討した。 $\mathrm{PbO}$ と $\mathrm{SiO}_{2}$, $\mathrm{Al}_{2} \mathrm{O}_{3}, \mathrm{Fe}_{2} \mathrm{O}_{3}$ との $\mathrm{Pb}$ 複合酸化物に関しては, 状態 図 ${ }^{19-21)}$ が報告されており, 数多くの $\mathrm{Pb}$ 複合酸化物が存 在する。状態図の例を Fig. $6^{21)}$ に示す。前節の結果か ら, 焼却炉底灰に含まれる $\mathrm{Pb}$ は $\mathrm{Pb}^{2+}$ であることが判 明しているが, $\mathrm{Ca}-\mathrm{Pb}-\mathrm{O}$ 系の複合酸化物は $\mathrm{Pb}^{4+}$ の化 合物のみしか報告がなく, $\mathrm{Ca}-\mathrm{Pb}-\mathrm{O}$ 系を本検討から除 外した。したがって, $\mathrm{Pb}-\mathrm{Si}-\mathrm{O}, \mathrm{Pb}-\mathrm{Al}-\mathrm{O}, \mathrm{Pb}-\mathrm{Fe}-\mathrm{O}$ 系 における $\mathrm{Pb}^{2+}$ の $\mathrm{Pb}$ 複合酸化物を対象として検討を進 めた。

状態図により, $\mathrm{Pb}$ 複合酸化物の融点は焼却炉の炉内 温度範囲を含む $700 \sim 900^{\circ} \mathrm{C}$ の領域にあった。複数の酸 化物が加熱されて複合酸化物を形成する反応においては, 生成物質の融点近傍まで加熱されるとその反応速度は増 大寸るので, 焼却炉内にて $\mathrm{Pb}$ 複合酸化物が生成する可 能性は高いと考えられた。

ただ， $\mathrm{Pb}$ あるいは $\mathrm{Pb}$ 化合物では $0,2,4$ 価の化合物 が存在することから, 反応場の酸素濃度を考慮した複合 酸化物種の検討が必要であると考えた。そこで, 平衡計 算ソフト FactSage の Predominant（主安定領域作図） 機能を用いて, 所定温度, ガス濃度 ${ }^{22)}$ において $\mathrm{PbO}$ が $\mathrm{SiO}_{2}, \mathrm{Al}_{2} \mathrm{O}_{3}, \quad \mathrm{Fe}_{2} \mathrm{O}_{3}$ と複合酸化物を生成しうるかどう 
かについて平衡計算を行った。平衡計算の前提条件を Table 2 に示す。ここで，ごみ焼却処理の際に $\mathrm{O}_{2}, \mathrm{CO}_{2}$, $\mathrm{CO}$ 濃度は常に变動することから，その範囲設定におい ては通常のごみ焼却炉内の平均的なガス組成を含む広い 範囲に設定して計算を実行した。また， $\mathrm{Pb}$ と $\mathrm{Si} ， \mathrm{Al}$ ， $\mathrm{Fe}$ との存在比は，焼却炉底灰に含まれる $\mathrm{Pb}$ が微量で あることから $\mathrm{Si}, \mathrm{Al}, \mathrm{Fe}$ が大部分を占める存在比と設 定した。

Fig. 7 に, $\mathrm{Pb}-\mathrm{Si}-\mathrm{O}$ 系, $\mathrm{P}\left(\mathrm{CO}_{2}\right)-\mathrm{P}\left(\mathrm{O}_{2}\right)$ の 800 $1,200^{\circ} \mathrm{C}$ における平衡計算の結果を示す。 $1,000^{\circ} \mathrm{C}$ 以上の 低 $\mathrm{O}_{2}$ 分圧下では金属 $\mathrm{Pb}$ が生成し，温度上昇に伴い金 属 $\mathrm{Pb}$ が生成する $\mathrm{P}\left(\mathrm{O}_{2}\right)$ 屯上昇するが，焼却炉内を想 定した Table 2 の前提条件の温度・ガス組成（Fig. 7 中斜線部分）では $\mathrm{Pb}^{2}+$ の複合酸化物 $\mathrm{PbSiO}_{3}$ が熱力学

Table 2 The precondition in calculation

\begin{tabular}{|c|c|c|c|}
\hline \begin{tabular}{|l|} 
Temperature \\
\end{tabular} & \multicolumn{3}{|c|}{$800,900,1000,1100,1200^{\circ} \mathrm{C}$} \\
\hline $\mathrm{O}_{2}$ concentration & \multicolumn{3}{|c|}{$1 \sim 100 \%$} \\
\hline $\mathrm{CO}_{2}$ concentration & \multicolumn{3}{|c|}{$1 \sim 100 \%$} \\
\hline $\mathrm{H}_{2} \mathrm{O}$ concentration & \multicolumn{3}{|c|}{$20 \%$} \\
\hline CO concentration & \multicolumn{3}{|c|}{$1 \sim 100 \mathrm{ppm}$} \\
\hline Elemental ratio & $\begin{array}{c}\mathrm{Si} /(\mathrm{Si}+\mathrm{Pb})= \\
0.5 \sim 1.0\end{array}$ & $\begin{array}{c}\mathrm{Al} /(\mathrm{Al}+\mathrm{Pb})= \\
0.9231 \sim 1.0\end{array}$ & $\begin{array}{c}\mathrm{Fe} /(\mathrm{Fe}+\mathrm{Pb})= \\
0.9091 \sim 1.0\end{array}$ \\
\hline \multirow{12}{*}{$\begin{array}{l}\text { Product database } \\
\text { ( } \mathrm{Pb} \text { compounds only) }\end{array}$} & $\mathrm{Pb}$ & $\mathrm{Pb}$ & $\mathrm{Pb}$ \\
\hline & $\mathrm{PbO}$ & $\mathrm{PbO}$ & $\mathrm{PbO}$ \\
\hline & $\mathrm{PbO}_{2}$ & $\mathrm{PbO}_{2}$ & $\mathrm{PbO}_{2}$ \\
\hline & $\mathrm{Pb}_{3} \mathrm{O}_{4}$ & $\mathrm{~Pb}_{3} \mathrm{O}_{4}$ & $\mathrm{~Pb}_{3} \mathrm{O}_{4}$ \\
\hline & $\mathrm{Pb}(\mathrm{OH})_{2}$ & $\mathrm{~Pb}(\mathrm{OH})_{2}$ & $\mathrm{~Pb}(\mathrm{OH})_{2}$ \\
\hline & $(\mathrm{PbO})_{3}\left(\mathrm{H}_{2} \mathrm{O}\right)$ & $(\mathrm{PbO})_{3}\left(\mathrm{H}_{2} \mathrm{O}\right)$ & $(\mathrm{PbO})_{3}\left(\mathrm{H}_{2} \mathrm{O}\right)$ \\
\hline & $\mathrm{PbCO}_{3}$ & $\mathrm{PbCO}_{3}$ & $\mathrm{PbCO}_{3}$ \\
\hline & $\mathrm{PbC}_{2} \mathrm{O}_{4}$ & $\mathrm{PbC}_{2} \mathrm{O}_{4}$ & $\mathrm{PbC}_{2} \mathrm{O}_{4}$ \\
\hline & $(\mathrm{PbO})\left(\mathrm{PbCO}_{3}\right)$ & $(\mathrm{PbO})\left(\mathrm{PbCO}_{3}\right)$ & $(\mathrm{PbO})\left(\mathrm{PbCO}_{3}\right)$ \\
\hline & $\mathrm{PbSiO}_{3}$ & $(\mathrm{PbO})\left(\mathrm{Al}_{2} \mathrm{O}_{3}\right)$ & $\mathrm{PbFe}_{4} \mathrm{O}_{7}$ \\
\hline & $\mathrm{Pb}_{2} \mathrm{SiO}_{4}$ & $(\mathrm{PbO})\left(\mathrm{Al}_{2} \mathrm{O}_{3}\right)_{6}$ & $\mathrm{PbFe}_{10} \mathrm{O}_{16}$ \\
\hline & $(\mathrm{PbO})_{4}\left(\mathrm{SiO}_{2}\right)$ & $(\mathrm{PbO})_{2}\left(\mathrm{Al}_{2} \mathrm{O}_{3}\right)$ & $\mathrm{Pb}_{2} \mathrm{Fe}_{2} \mathrm{O}_{5}$ \\
\hline
\end{tabular}

的に安定な化合物であることを確認した。また，同様の 計算にて $(\mathrm{PbO})\left(\mathrm{Al}_{2} \mathrm{O}_{3}\right)_{6}, \quad \mathrm{PbFe}_{10} \mathrm{O}_{18}$ が熱力学的に安 定な化合物であることを確認し，焼却炉内にて $\mathrm{Pb}$ は $\mathrm{Pb}^{2+}$ の複合酸化物の形態をとる可能性があると推定し た。

\section{3 試薬を用いて合成した $\mathrm{Pb}$ 化合物のキャラクタリ ゼーション}

焼却炉底灰 $\mathrm{A} \sim \mathrm{E}$ の XANES スペクトルと比較する 標準試料スペクトルを得るために，試薬を用いて $\mathrm{Pb}$ 複 合酸化物の合成を試みた。XRD 測定から目的物質の ピークを帰属できたので, $\mathrm{Pb}$ 複合酸化物が形成され たと考えられた。しかし， $\mathrm{PbO}-\mathrm{Al}_{2} \mathrm{O}_{3}, \mathrm{PbO}-\mathrm{Fe}_{2} \mathrm{O}_{3}$ 系 はXRD 測定結果から出発物質の $\mathrm{PbO}, \mathrm{Al}_{2} \mathrm{O}_{3}, \mathrm{Fe}_{2} \mathrm{O}_{3}$, あるいは帰属不可能な未知相のピークのみ が存在し, 目的物質の $\mathrm{Pb}$ 複合酸化物のピー クは帰属できなかった。焼成温度を上げて 合成を試みたが，融解物と粉末物の混在した 試料が得られ，XRD 解析結果であ目的物質 を示すピークは存在しなかった。したがって 本実験条件に打いては $\mathrm{PbO}-\mathrm{Al}_{2} \mathrm{O}_{3}, \mathrm{PbO}-$ $\mathrm{Fe}_{2} \mathrm{O}_{3}$ 系では $\mathrm{Pb}^{2+}$ の複合酸化物は形成さ れなかったことを確認した。この結果より, $\mathrm{PbO}$ と $\mathrm{SiO}_{2}$ の組み合わせが最も複合酸化物 を形成しやすいと考え, 以後は $\mathrm{PbSiO}_{3}$ を用 いて焼却炉底灰中の $\mathrm{Pb}$ の化合物形態解析を 進めた。

$\mathrm{PbO}-\mathrm{SiO}_{2}$ 系は，非晶質と結晶質の 2 種が 存在する。そのため, 非晶質・結晶質の両方 を合成してXANESスペクトルの比較を 行った。Fig. 8 に, $\mathrm{PbO}, \mathrm{PbSiO}_{3}$ (結晶質),

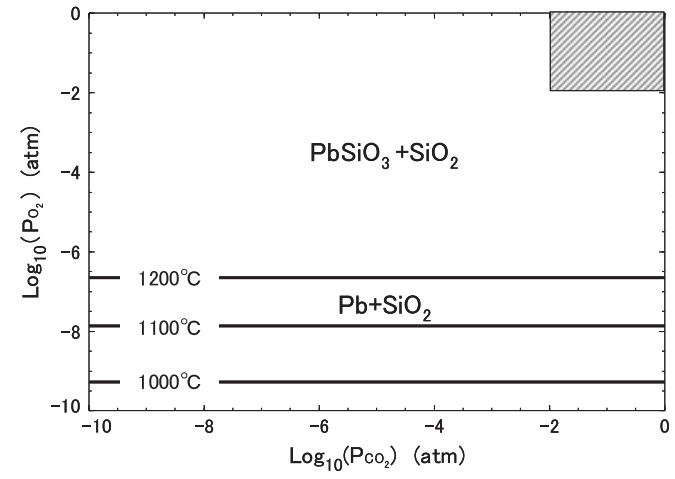

Fig. 7 The example of a result of calculation (The shaded portion in the upper right part shows the range of the gas composition of the calculation)

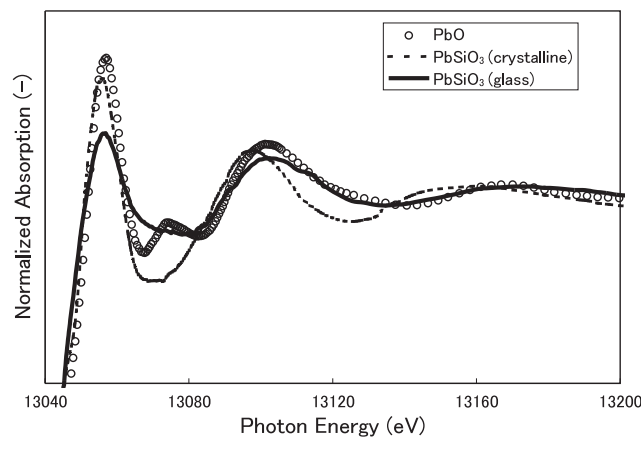

Fig. $8 \mathrm{~Pb}$ L 3 XANES edge spectra for $\mathrm{PbO}$, $\mathrm{PbSiO}_{3}$ (crystalline) and $\mathrm{PbSiO}_{3}$ (glass) 
$\mathrm{PbSiO}_{3}$ (非晶質) の $\mathrm{Pb}$ L 3 XANES スペクトルを示 す。 $\mathrm{PbO}$ と比較して $\mathrm{PbSiO}_{3}$ (結晶質) は吸収端ピーク の強度が少し低下し， $13,070 \mathrm{eV}$ 付近のピークが見られ なくなる。 $\mathrm{PbSiO}_{3}$ (非晶質) では吸収端ピークの強度 がさらに低下し, 第 2 ピークが高エネルギー側へシフト することがわかる。このため, 同じ $\mathrm{PbSiO}_{3}$ でも結晶質 と非晶質では, XANES スペクトル形状に違いがあるこ とがわかる。

\section{4 非晶質, 結晶質の $\mathrm{PbSiO}_{3}$ を用いた焼却炉底灰中 $\mathrm{Pb}$ の化合物形態解析}

このスペクトルを標準物質スペクトルとして用いて, 焼却炉底灰に含まれる $\mathrm{Pb}$ の化合物形態の解析を行った。 非晶質, 結晶質の $\mathrm{PbSiO}_{3}, \mathrm{PbO}$ と Fig. 4 中の焼却炉 底灰 $\mathrm{A} \sim \mathrm{E}$ のスペクトルを比較して Fig. 9 に示す。ま た, 光子エネルギー範囲 $12,985 \sim 13,200 \mathrm{eV}$ において, 焼却炉底灰の $\mathrm{Pb}$ スペクトルと標準物質とのパターン フィッティングを実施した結果を Table 3 に示す。焼 却炉底灰 $\mathrm{B}, \mathrm{D}, \mathrm{E}$ ではすべての $\mathrm{Pb}$ が $\mathrm{PbSiO}_{3}$ (非晶質)

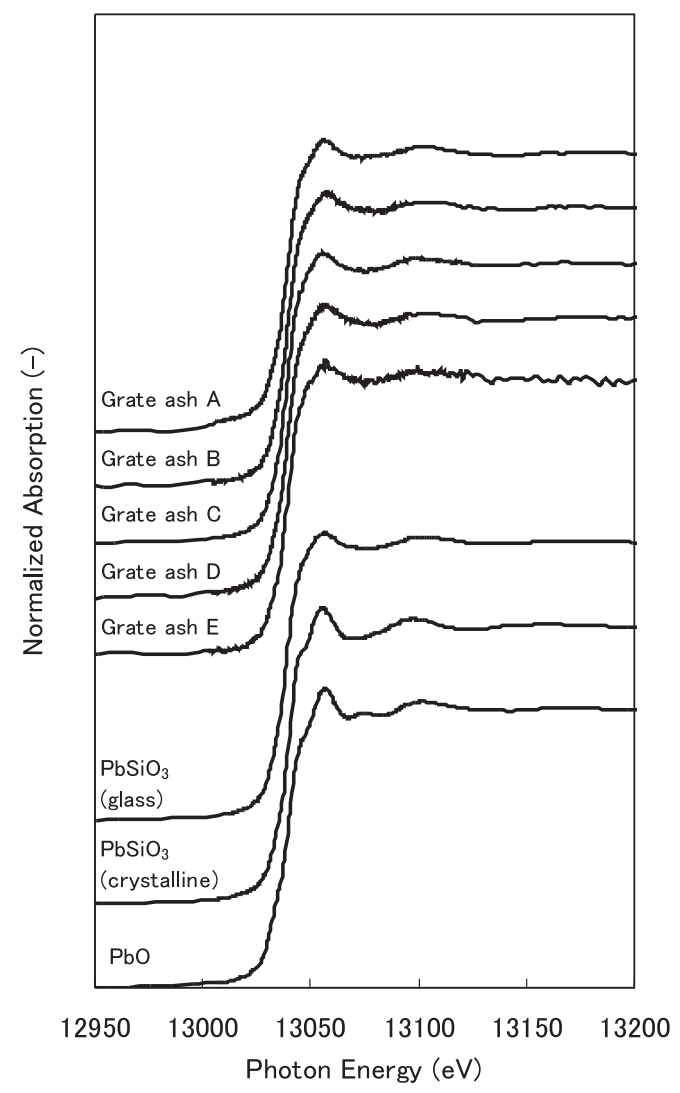

Fig. $9 \mathrm{~Pb}$ L 3 edge XANES spectra for grate ash $\mathrm{A} \sim \mathrm{E}, \mathrm{PbO}, \mathrm{PbSiO}_{3}$ (crystalline) and $\mathrm{PbSiO}_{3}$ (glass)
Table 3 Percentages of the chemical forms relative to the total $\mathrm{Pb}$ obtained by LCF in grate ash $\mathrm{A} \sim \mathrm{E}$

\begin{tabular}{|c|c|c|c|c|c|}
\hline \multicolumn{2}{|c|}{ Sample } & $\mathrm{PbO}$ & $\begin{array}{c}\mathrm{PbSiO}_{3} \\
\text { (crystalline) }\end{array}$ & $\begin{array}{c}\mathrm{PbSiO}_{3} \\
\text { (glass) }\end{array}$ & $\mathrm{R}$ \\
\hline \multirow{4}{*}{$\begin{array}{c}\text { Grate } \\
\text { ash }\end{array}$} & A & 0 & 16 & 84 & 0.015 \\
\cline { 2 - 6 } & $\mathrm{B}$ & 0 & 0 & 100 & 0.007 \\
\cline { 2 - 6 } & $\mathrm{C}$ & 0 & 29 & 71 & 0.009 \\
\cline { 2 - 6 } & $\mathrm{D}$ & 0 & 0 & 100 & 0.007 \\
\cline { 2 - 6 } & $\mathrm{E}$ & 0 & 0 & 100 & 0.008 \\
\hline
\end{tabular}

である結果となり, 焼却炉底灰 $\mathrm{A}, \mathrm{C}$ では非晶質, 結晶 質の $\mathrm{PbSiO}_{3}$ の混合物である結果が得られた。しかし, $\mathrm{PbSiO}_{3}$ (非晶質) のみでパターンフィッティングを 行っても $\mathrm{R}$ 值がほとんど変わらなかった。この結果か ら, 焼却炉底灰 $\mathrm{A}, \mathrm{C}$ であ他の試料之同様に $\mathrm{PbSiO}_{3}$ (非 晶質）が主に含まれている可能性が高いと推測された。

したがって，焼却炉底灰 $\mathrm{A} \sim \mathrm{E}$ 中の $\mathrm{Pb}$ はほぼすべてが $\mathrm{PbSiO}_{3}$ (非晶質) であると考えられた。非晶質である ことは, 焼却炉内にて $\mathrm{Pb}$ が他の元素と複合酸化物を形 成した際に融点を超える焼却炉内の温度雾囲気にさらさ れ, 炉外へ排出された際に灰押出機等にて急冷されたた めと考えられた。

したがって, 焼却炉底灰含有の $\mathrm{Pb}$ は $\mathrm{Pb}^{2+}$ の酸化物 形態をとり, しかむ単純酸化物 $\mathrm{PbO}$ ではなく, $\mathrm{Si}$ 等の 他の陽イオンと非晶質の複合酸化物を形成していると考 えられた。本結果とこの手法は, 焼却灰の非溶融処理で あるエージング処理 ${ }^{23)}$ や焼成処理 ${ }^{24)}$ の検討において $\mathrm{Pb}$ の出発物質の化合物形態が明確になり, それぞれの無害 化処理の反応過程を追跡する上での有益な基盤デー夕と なりうると考えられた。また, 焼却炉底灰中の $\mathrm{Pb}$ が非 晶質の $\mathrm{PbSiO}_{3}$ であると推測されたことにより, 既報の 鉛ガラス中の $\mathrm{Pb}$ 分離方法 ${ }^{25,26)}$ を参考に焼却炉の操業状 態を制御することで, $\mathrm{Pb}$ の飛灰等への移行量増加を狙 う等の取り組みを発案できると考えられた。

\section{5 焼却残椬の $\mathrm{Pb}$ の化合物形態解析結果}

焼却炉底灰 A と E を採取した焼却炉から排出された焼 却炉底灰, ボイラ死, 減温塔灰 (E工場のみ), 集塵灰 (E 工場は時期を变えて採取した 2 種）の Pb L 3 XANES スペクトルを標準試料 $\mathrm{PbSiO}_{3}$ (非晶質), $\mathrm{PbO}, \mathrm{PbCO}_{3}$, $\mathrm{PbCl}_{2}$ とともに Fig. 10 に示す。また, 前節 3.3 と同様 に, Fig. 10 の光子エネルギー範囲において実施した各 種焼却残椬の $\mathrm{Pb}$ スペクトルと標準物質とのパターン フィッティング結果を Table 4 に示す。

ボイラ灰 $\mathrm{A}$ の $\mathrm{Pb}$ スペクトルは, $\mathrm{PbCl}_{2}, \mathrm{PbSiO}_{3}$ （結 晶質), $\mathrm{PbSiO}_{3}$ (非晶質) の混合スペクトルに類似し, $\mathrm{PbSiO}_{3}$ (非晶質) の割合が最も高くなった。また，ボイ 
ラ灰 $\mathrm{E}$ の $\mathrm{Pb}$ スペクトルは, $\mathrm{PbCO}_{3}, \mathrm{PbSiO}_{3}$ (非晶質) の混合スペクトルであり, ボイラ灰 $\mathrm{A}$ 同様に $\mathrm{PbSiO}_{3}$ （非晶質）の割合が高い結果となった。ただ，塩化物や 炭酸化物の存在む示唆されたことから，ボイラ灰は，焼 却炉から飛散した $\mathrm{PbSiO}_{3}$ が主であると推測された。

減温塔灰の $\mathrm{Pb}$ スペクトル形状は, $\mathrm{PbSiO}_{3}$ (結晶質), $\mathrm{PbSiO}_{3}$ （非晶質）の混合スペクトルであった。減温塔

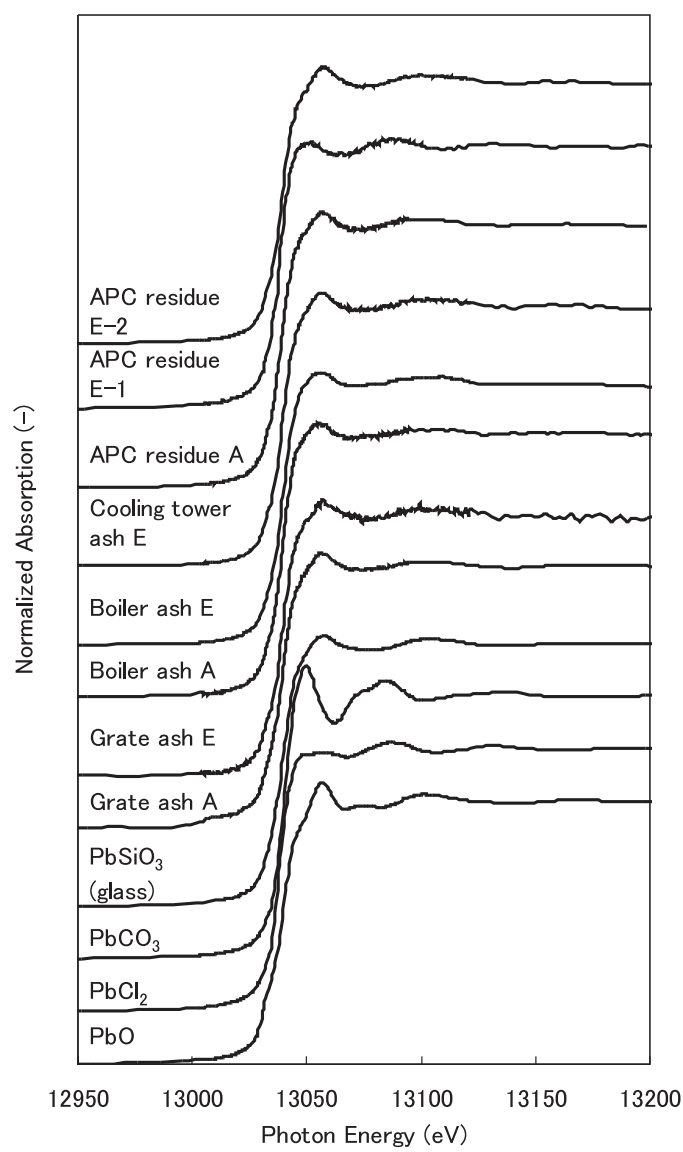

Fig. $10 \mathrm{~Pb} \mathrm{~L} 3$ edge XANES spectra for municipal solid-waste incinerator residues.
灰では, $\mathrm{PbCl}_{2}$ や $\mathrm{PbCO}_{3}$ などの化合物の存在は示唆さ れなかったことより, 減温塔で落下して減温塔灰として 排出された粒子には, $\mathrm{Pb}$ は酸化物形態のみ含まれると 推測された。

ボイラ灰, 減温塔灰の $\mathrm{Pb}$ の化合物形態が $\mathrm{PbSiO}_{3}$ を 主とすることより, ボイラ死, 減温塔灰の $\mathrm{Pb}$ の化合物 形態は, 集塵灰よりは焼却炉底灰に近いことが明らかに なった。近年, ボイラ死, 減温塔灰を集塵灰に混合して 無害化処理するプロセスが増えているが，この場合ボイ ラ灰，減温塔灰に含まれる $\mathrm{Pb}$ 化合物が飛灰の無害化処 理に与える影響は小さいと推測された。

集塵灰 $\mathrm{A}$ の $\mathrm{Pb}$ スペクトル形状は, $\mathrm{PbCl}_{2}, \mathrm{PbO}$, $\mathrm{PbSiO}_{3}$ (結晶質), $\mathrm{PbSiO}_{3}$ (非晶質) の混合スペクトル であった。焼却炉底灰 $\mathrm{A}$ ではみられなかった $\mathrm{PbCl}_{2}$ が みられることにより, $\mathrm{Pb}$ の一部が塩化物化したと考え られた。一方, 集塵灰 E- 1 は集塵灰 A や E- 2 とは異 なるスペクトル形状であり，パターンフィッティング の結果, 塩化物の形態で 100\% 存在する結果が得られ た。また， $\mathrm{E}-2$ は $\mathrm{PbSiO}_{3}$ (結晶質) と $\mathrm{PbSiO}_{3}$ （非晶 質）の混合スペクトルであり, $\mathrm{PbCl}_{2}$ の存在は示唆さ れなかった。集塵灰では， $\mathrm{Pb}$ の主たる化合物形態が塩 化物の場合之酸化物の場合があることが判明した。集 塵灰に拈ける本結果は, $\mathrm{Pb}$ が塩化物の形態で存在す るとした高岡らの報告 ${ }^{12)}$ と一部が合致するが，同じ工 場であ $\mathrm{Pb}$ の化合物形態が異なる集塵灰が排出される ことを示唆できた。このことは， $\mathrm{Pb}$ 溶出量の異なる集 塵死が同一工場にて発生することを示唆しており，飛灰 の無害化処理条件検討においては $\mathrm{Pb}$ 溶出量の時期的 変動を考慮した処理条件を確立する必要があると考え られた。

\section{4.まと め}

焼却残椬に含有される微量元素 $\mathrm{Pb}$ の化合物形態解析 により，焼却残椬に含まれる $\mathrm{Pb}$ の無害化・資源化技術

Table 4 Percentages of the chemical forms relative to the total $\mathrm{Pb}$ obtained by LCF in municipal solidwaste incinerator residues

\begin{tabular}{|l|c|c|c|c|c|c|c|}
\hline \multicolumn{2}{|c|}{ Sample } & $\mathrm{PbCO}_{3}$ & $\mathrm{PbCl}_{2}$ & $\mathrm{PbO}$ & $\begin{array}{c}\mathrm{PbSiO}_{3} \\
\text { (crystalline) }\end{array}$ & $\begin{array}{c}\mathrm{PbSiO}_{3} \\
\text { (glass) }\end{array}$ & $\mathrm{R}$ \\
\hline \multirow{2}{*}{ Grate ash } & $\mathrm{A}$ & 0 & 0 & 0 & 16 & 84 & 0.015 \\
\cline { 2 - 9 } & $\mathrm{E}$ & 0 & 0 & 0 & 0 & 100 & 0.008 \\
\hline \multirow{2}{*}{ Boiler ash } & $\mathrm{A}$ & 0 & 25 & 0 & 28 & 48 & 0.007 \\
\cline { 2 - 9 } & $\mathrm{E}$ & 14 & 0 & 0 & 0 & 86 & 0.006 \\
\hline \multirow{3}{*}{ Cooling tower ash } & $\mathrm{E}$ & 0 & 0 & 0 & 11 & 89 & 0.007 \\
\hline \multirow{3}{*}{ APC residue } & $\mathrm{A}$ & 0 & 29 & 15 & 14 & 42 & 0.005 \\
\cline { 2 - 9 } & $\mathrm{E}-1$ & 0 & 100 & 0 & 0 & 0 & 0.012 \\
\cline { 2 - 9 } & $\mathrm{E}-2$ & 0 & 0.0 & 0 & 13 & 87 & 0.007 \\
\hline
\end{tabular}


確立に反映できる以下の知見が得られた。

1 ）焼却炉底灰含有の $\mathrm{Pb}$ は $\mathrm{Pb}^{2+}$ の酸化物形態をと るが, 単純酸化物ではなく, 非晶質の複合酸化物 $\mathrm{PbSiO}_{3}$ を主に含むことがわかった。本結果は, 今回の測定に供した全連続ストーカ式ごみ焼却炉 から採取した 5 種の焼却炉底灰すべてに対して得 られた結果であるため, 焼却炉底灰中の $\mathrm{Pb}$ の存 在形態として一般的である可能性が高いと考えら れた。

2 ) ボイラ灰, 減温塔灰, 集塵灰の一部屯同様に非晶 質の $\mathrm{PbSiO}_{3}$ を含むが，ごみ質や操業状態等の違 いにより，集塵灰は塩化物の単一相となる場合が あると考えられた。

\section{[謝 辞 $]$}

本報告の $\mathrm{Pb}$ XANES データは, (財)高輝度光科学 研究センターにおける SPring-8 共用ビームライン 利用研究課題 (2001 A $0447-\mathrm{NX}-\mathrm{np}, 2004$ B $0283-$ NI-np）にて，宇留賀博士のご協力のもとで実施し ました。この場を借りまして感謝の意を表します。

\section{参 考文献}

1) 中野彰子, 本幡照文, 崎田省吾, 島岡隆行 : 人工的土 壤生成因子の作用に伴う焼却残椬の鉛不溶化現象, 第 13 回廃棄物学会研究発表会講演論文集, pp. 841-843 (2002)

2) 高岡昌輝, 蔵本康宏, 武田信生, 藤原健史：X 線光電 子分光による飛灰表面上の亜鉛, 鉛, 銅の化学形態の 推定, 廃棄物学会論文誌, 第 12 巻, 第 3 号, pp $102-$ 111 (2001)

3 ) 大木 章, 隈部康誉, 中村有樹, 中島常憲, 高梨啓和 : $\mathrm{X}$ 線光電子分光による石炭飛灰㧍よび廃棄物焼却飛灰 の分析, 第 13 回廃棄物学会研究発表会講演論文集, pp. $875-877$ (2002)

4) 宇田川康夫：X 線吸収微細構造 — XAFS の測定之 解析一, 学会出版センター (1993)

5 ) 佐藤 登: XANES と EXAFS, 表面技術, 第 48 巻, 第 10 号, p. 998 (1997)

6 ) 山本 浩, 名越正泰, 中原啓介, 藤澤能成, 秋山肇 : 飛灰の液体キレート剂による鉛安定化機構, 第 11 回廃 棄物学会研究発表会講演論文集, pp. 892-894（2000）

7 ) 山本 浩, 名越正泰, 岩崎敏彦, 中原啓介, 藤澤能成, 高岡昌輝, 武田信生 : 主灰含有鉛の化合物形態解析, 第 12 回廃棄物学会研究発表会講演論文集, pp. $872-$ 874 (2001)

8 ) 山本 浩, 名越正泰, 岩崎敏彦, 中原啓介, 奈良久夫, 藤沢能成 : 焼却残椬含有元素の化合物形態解析, 第 23 回全国都市清掃研究発表会講演論文集, pp. 273-275 (2002)

9) 山本 浩, 名越正泰, 藤沢能成: 焼却残渣における微量
元素の化合物形態解析, 2002 環境工学総合シンポジゥ 么講演論文集, pp. 214-216（2002）

10）名越正泰, 河野崇史, 山本 浩, 高岡昌輝, 宇留賀朋哉, 小林克己：ごみ焼却飛灰中の $\mathrm{Hg}$ の化学結合状態, 第 5 回 XAFS 討論会講演要旨集, pp. 43-44（2002）

11）高岡昌輝, 武田信生, 山本 浩, 名越正泰, 藤澤能成: ごみ焼却飛灰中の水銀の化学結合状態, 第 13 回廃棄物 学会研究発表会講演論文集, pp. 881-883（2002）

12) M. Takaoka, T. Yamamoto, T. Tanaka, N. Takeda, K. Oshita and T. Uruga: Direct Speciation of Lead, Zinc and Antimony in Fly Ash from Waste Treatment Facilities by XAFS Spectroscopy, Physica Scripta, Vol. T 115, pp. 943-945(2005)

13) V.R. Mastelaro, E. D. Zanotto, N. Lequeux and R. Cortes: Relationship between Short-range Order and Ease of Nucleation in $\mathrm{Na}_{2} \mathrm{Ca}_{2} \mathrm{Si}_{3} \mathrm{O}_{9}$, $\mathrm{CaSiO}_{3}$ and $\mathrm{PbSiO}_{3}$ Glasses, Journal of Non-Crystalline Solids, Vol. 262, pp. $191-199$ (2000)

14) D. Roberts, A. C. Scheinost and D. L. Sparks : Zinc Speciation in Contaminated Soils Combining Direct and Indirect Characterization Methods. In Geochemical and Hydrological Reactivity of Heavy Metals in Soils; H. M. Selim, and W. L. Kingery (Eds.) ; Lewis Publishers: Boca Raton, FL, pp. 188 - 227 (2003)

15) T. Ressler, J. Wong, J. Roos and I. L. Smith : Quantitative Speciation of $\mathrm{Mn}$-bearing Particulates Emitted from Autos Burning (Methylcyclopentadienyl) Manganese Tricarbonyl-added Gasolines Using XANES Spectroscopy, Environ. Sci. Technol. Vol. 34, pp. 950-958 (2000)

16) M. C. Hsiao, H. P. Wang and Y.W. Yang : EXAFS and XANES Studies of Copper in a Solidified Fly Ash, Environ. Sci. Technol., Vol. 35, pp. $2532-$ 2535 (2001)

17) M. Takaoka, A. Shiono, K. Nishimura, T. Yamamoto, T. Uruga, N. Takeda, T. Tanaka, K. Oshita, T. Matsumoto and H. Harada: Dynamic Change of Copper in Fly Ash during de Novo Synthesis of Dioxins, Environ. Sci. Technol., Vol. 39, pp. $5878-$ 5884 (2005)

18) M. Takaoka, T. Yamamoto, A. Shiono, N. Takeda, K. Oshita, T. Matsumoto and T. Tanaka: The Effect of Copper Speciation on the Formation of Chlorinated Aromatics on Real Municipal Solid Waste Incinerator Fly Ash, Chemosphere, Vol. 59, pp. $1497-1505$ (2005)

19) E. M. Levin, C. R. Robbins and H.F. McMurdie (Ed.) : Phase Equilibria Diagrams Volume I: Oxides and Salts, The American Ceramic Society Publications, p. 59 (1964)

20) E. M. Levin, C. R. Robbins and H.F. McMurdie (Ed.) : Phase Equilibria Diagrams Volume I : Oxides and Salts, The American Ceramic Society 
Publications, p. 147 (1964)

21) E. M. Levin and H.F. McMurdie (Ed.): Phase Equilibria Diagrams Volume III: Oxides and Salts, The American Ceramic Society Publications, p. 250 (1975)

22）宮越靖宏, 西野雅明, 立福輝生, 山本 浩, 横山隆, 鈴木 実 : 次世代型スト一カ式焼却炉による低空気比燃 焼の実現とその効果, 第 14 回廃棄物学会研究発表会講 演論文集，pp. 638-640（2003）

23）井澤㻟磨, 高岡昌輝, 大下和徹, 松本忠生, 武田信 生：エージングによる都市ごみ焼却主灰中重金属の安 定化機構の解明，第 15 回廃棄物学会研究発表会講演論 文集，pp. 1075-1077（2004）
24）櫻井あや, 高岡昌輝, 大下和徹, 松本忠生, 武田信 生：焼成処理における都市ごみ焼却灰中重金属の挙動

II 焼成温度・時間・雾囲気の影響——，第 15 回 廃棄物学会研究発表会講演論文集, pp. 754-756 (2004)

25）稲野浩行, 橋本祐二, 工藤和彦：還元溶融による廃ブ ラウン管ガラスからの鉛分離，北海道立工業試験場報 告第 304 号, pp. 71-77 (2005)

26）柿本幸司, 尾川博昭, 加藤安彦, 泊 正雄 : ソーダガラ スビンクズおよび液晶用テレビブラウン管ガラス等の スラグ改質材としての利用, 第 9 回廃衰物学会研究発 表会講演論文集，pp. 546-548（1998）

\title{
Investigation of Chemical States for $\mathrm{Pb}$ of MSWI Residues
}

\author{
Hiroshi Yamamoto*, Masayasu Nagoshi**, Takashi Yokoyama*** \\ Masaki Takaoka**** and Nobuo Takeda**** \\ * JFE R\&D Corporation \\ ** JFE Steel Corporation \\ *** JFE Engineering Corporation \\ **** Department of Environmental Engineering, Graduate School of Engineering, Kyoto University \\ ${ }^{\dagger}$ Correspondence should be addressed to Hiroshi Yamamoto : \\ JFE R\&D Corporation \\ ( 1-1, Minamiwatarida-machi, Kawasaki-ku, Kawasaki-city, Kanagawa, 211-0855 Japan)
}

\begin{abstract}
The chemical state of the trace element $\mathrm{Pb}$, which is contained in municipal solid waste incineration residues discharged from a stoker-type incinerator were investigated by using XAFS spectroscopy at beam line BL 01 B 1 in SPring-8. The chemical states of Pb contained in grate ashes were at an oxide state of $\mathrm{Pb}^{2+}$, and it was observed that the amorphous double-oxide compound $\mathrm{PbSiO}_{3}$ was formed. Boiler ashes were mixtures of the compound oxide of the amorphous $\mathrm{PbSiO}_{3}$ and either the chloride of $\mathrm{Pb}^{2+}$ or the carbonate. As for cooling tower ash, no existence of the chloride was observed only the amorphous $\mathrm{PbSiO}_{3}$. In $\mathrm{APC}$ residues, if the discharged time in the same facility was different, there were both cases : either the chloride, or the amorphous $\mathrm{PbSiO}_{3}$.
\end{abstract}

Key words : MSWI, residue, $\mathrm{Pb}$, chemical states, XAFS, double--oxide 